\title{
0 desenvolvimento sustentável por meio da biossegurança e a responsabilidades sociais da empresa
}

The sustainable development by means of the biosecure and the social responsibilities of the company

\author{
Lara Caxico ${ }^{1}$ \\ Marlene Kempfer ${ }^{2}$
}

\begin{abstract}
Resumo
A biossegurança é um direito fundamental. Nesse sentido, todos que atuam em atividades que possam causar risco à vida humana devem ficar sob especial vigilância do Estado. No setor da atividade econômica, e sob uma perspectiva histórica, pode-se indicar a empresa como importante foco de estudo diante das questões da biossegurança. Por lidar com seres humanos e produzir externalidades negativas ao meio ambiente esta deve ser responsabilizada pelos danos que causa a estes. Desde a Revolução Industrial e até a contemporaneidade são muitos os relatos de atuação empresarial, nem sempre ética, diante dos empregados, consumidores e meio ambiente. Em busca de mudar esse cenário o Estado passou a intervir sobre este domínio visando, além disso, proteger as relações empresariais, juridicizando-as. Esta intervenção, por meio de leis, de fiscalização, de incentivo, tem a finalidade de valorizar o trabalho humano, defender o consumidor e o meio ambiente de modo preventivo e, em casos necessários, de precaução. São os cuidados jurídicos para promover um desenvolvimento econômico sustentável.
\end{abstract}

Palavras-Chaves: Desenvolvimento sustentável; Biossegurança; Responsabilidade social empresarial.

\begin{abstract}
The bio security is a basic right. In this direction, all that act in activities that can cause risk to the life human being must be under special monitoring of the State. In the sector of the economic activity, and under a historical perspective, the company can be indicated as important focus of study ahead of the questions of the bio security. By dealing with human beings and producing negative interferences to the environment this must be made responsible by the damages that cause to these. Since the Industrial Revolution and until the present time the stories of enterprise performance are many, nor always ethical, ahead of the employees, consumers and environment. In search to change this scene the State started to intervine on this
\end{abstract}

${ }^{1}$ Graduanda da Universidade Estadual de Londrina, curso de Direito, bolsista CNPq do projeto de pesquisa Diálogos J urídicos e Filosóficos so bre a Intervenção do Estado no Domínio Econômico: Ética Empresarial à Luz do Regime Econômico Constitucional.

${ }^{2}$ Professora da Universidade de Londrina, doutora em Direito do Estado pela PUC-SP, coordenadora do projeto Diálogos J urídicos e Filosóficos sobre a Intervenção do Estado no Domínio Econômico: Ética Empresarial à Luz do Regime Econômico Constitucional.

Revista de Direito Púbuico, LondRINA, V. 6, N. 3, P. 120-138, OUT/DEZ. 2011. 


\section{0 desenvolvimento sustentável por meio da Biossegurança e as responsabilidades sociais da empresa}

domain being aimed at, moreover, to protect the enterprise relations and placing them inside of the law. This intervention, by means of laws, of fiscalization, incentive, has the purpose to value the human work, to defend the consumer and the environment in preventive way e, in necessary cases, of precaution. They are the legal cares to promote economic a development sustainable.

Keywords: Sustainable development; Biosecure; Enterprise responsibility.

\section{Considerações Iniciais}

A responsabilidade social empresarial no contexto do desenvolvimento sustentável é tema contemporâneo, mais precisamente, surgiu nas últimas quatro décadas, quando se constatou que ações no domínio econômico para viabilizar a sustentabilidade não eram somente responsabilidade do Estado.

Quando o movimento industrial ganhou força na Europa, mais especificamente na Inglaterra do século XVII, o comércio, ainda em expansão, não possuía legislação eficaz para regular o mercado, apenas rasas e espaças leis consuetudinárias. Os grandes empresários utilizavam-se da mão-de-obra do camponês que havia deixado o meio rural vislumbrando melhor qualidade de vida nas cidades. Desejo este que levou séculos para ser alcançado, afinal, devido à falta de leis trabalhistas da época, o indivíduo foi explorado e humilhado nas fábricas durantes longos anos.

0 ambiente (natureza) também não foi poupado do movimento capitalista industrial que, desenfreadamente, se desenvolvia. Tendo como meta o aumento do lucro, 0 empresário da Idade Moderna não se preocupava com a poluição que se produzia cotidianamente. As ruas, os rios e todo espaço físico possível, foi utilizado como local de despejo de lixos e dejetos industriais. Esse cenário permaneceu por séculos: durante boa parte da história das empresas não houve qualquer tipo de preocupação para com a vida em todas as suas formas.

No século XX, entretanto, nas décadas de 60 e 70 as primeiras considerações sobre as obrigações e responsabilidades sociais da empresa ganharam força e, desde então, diversas leis foram criadas com a intenção de barrar o desenvolvimento irresponsável e desmedido das empresas. 
A pesquisa desenvolvida no projeto Diálogos Jurídicos e Filosóficos sobre a Intervenção do Estado no Domínio Econômico: Ética Empresarial à Luz do Regime Econômico Constitucional visa mostrar, a partir de uma evolução histórico-legislativa, que a sustentabilidade ambiental e social das organizações, no aspecto econômico, é de sumária importância não só para a adequação da empresa conforme uma ordem jurídica constitucional, mas também para alcançar o reconhecimento social e assim a prosperidade da empresa. Essa adequação deve acontecer por meio de um vínculo duradouro com o trabalhador e consumidor: a confiança e o respeito.

A partir da análise das primeiras leis que regularam o comércio, das que abordavam especificamente a responsabilidade para com a vida e a saúde humana, bem como das mais recentes que orientam sustentavelmente o plano de ação empresarial, o presente estudo faz um recorte metodológico para o aspecto da biossegurança em paradigmas universais de segurança humana.

\section{Desenvolvimento industrial e responsabilidade social da empresa}

Durante toda a Idade Média 0 artesanato foi a principal forma de produção industrial. Em casa, 0 artesão e sua família produziam todos os bens necessários para o dia a dia do homem tais como sapatos, roupas, ferramentas e utensílios domésticos. Com 0 desenvolvimento do comércio monetário e o aumento populacional o mercado consumidor se ampliou e passou a ser necessário o aumento da produção de bens. Visando acelerar 0 processo produtivo, os grandes comerciantes passaram a reunir artesãos para produzirem em conjunto, destinando a cada um uma etapa da confecção e somando às suas forças a máquina. Surgem desse modo, as primeiras fábricas e linhas de produção que fomentariam o desenvolvimento industrial. (GARSCHAGEN, 1998, p. 20-60).

Com a maquinofatura o trabalhador se submeteu cada vez mais à produção mecanizada e a gerência direta do empresário. Sendo a mesma a responsável pela maioria das etapas de produção, o homem foi reduzido a um mero operador e não mais tinha a sabedoria da confecção. Sujeitos ao empresário, que possuía as máquinas e o controle da produção, os artesãos, antes acostumados com o ritmo do próprio trabalho, ficaram subordinados a disciplina das fábricas. (GARSCHAGEN, 1998, p. 20-60). 


\section{0 desenvolvimento sustentável por meio da Biossegurança e as responsabilidades sociais da empresa}

As jornadas de trabalho variavam entre doze e quatorze horas; destas, apenas poucos minutos eram destinados à alimentação. Os salários irrisórios não supriam as necessidades básicas do homem e da sua família o que fez com que mulheres e crianças passassem a integrar também a massa trabalhadora. Por serem estas mais fracas, e contribuírem menos com a produção, seus salários eram ainda menores que os dos homens, mesmo que trabalhassem por tempo equivalente. (GARSCHAGEN, 1998, p. 33-73).

Somado às jornadas excessivas, o ritmo acelerado das máquinas contribuía cada dia mais para a diminuição da qualidade de vida do trabalhador. Fábricas com pouca luminosidade, quentes, úmidas, insalubres e quase nem nenhuma ventilação tornavam a rotina de trabalho exaustiva e perigosa. Não havia dias de descanso, férias, pagamento por horas extras, nenhum tipo de beneficio ou lei que proibisse a exploração do trabalhador pelo empresário. (GARSCHAGEN, 1998, p. 33-73)

Reportando-se ao período da Revolução Industrial, percebe-se que o único interesse das empresas, naquela época, era maximizar seus lucros. As pessoas (trabalhadores, clientes,...), enquanto seres humanos, pouco importavam para as empresas. Por isso, a exploração da mão-de-obra feminina e infantil era bem mais comum que nos dias de hoje. (TEIXEIRA; TEIXEIRA; FONSECA, 2006, p.01)

No começo da Idade Moderna não havia conexão entre valores coletivos e valores individuais comerciais, por isso a idéia de uma ética social empresarial não era pauta de nenhuma reunião empresarial. Para os empresários não importava a qualidade de vida dos seus funcionários, muito menos se possuíam momentos de lazer e aprendizagem. 0 lucro maximizado, substituiria a mão de obra sempre que necessário, já que esta era abundante e barata. 0 trabalhador, quando não tinha mais condições de trabalhar pela velhice ou mesmo por doença adquirida no ambiente de trabalho era simplesmente substituído por um mais novo e eficiente, sem nenhum ônus para a empresa ou garantia e resguardo para aquele que a deixava.

Não havia nenhum tipo de lei ou proteção ao trabalhador. Durante a Revolução Industrial imperavam as leis de mercado como, por exemplo, a Lei da Oferta-Demanda: a produção aumentaria de acordo com o consumo da sociedade. Se para atender o mercado fosse preciso dobrar as jornadas de trabalho, esse seria o plano de ação dos empresários.

Revista de Direito Púbuco, Londrina, V. 6, N. 3, P. 120-138, OUT/DEZ. 2011. 
Contratar mais homens não estava em cogitação, afinal maiores gastos significavam menores lucros. A inexistência de leis trabalhistas fazia com que os indivíduos fossem mais facilmente explorados.

Vale ressaltar que durante a Revolução Industrial a falta de um compromisso ético empresarial era constatada não somente em relação aos funcionários das grandes indústrias, mas, também, para com o meio ambiente. Foi neste período que a poluição deixou de ser local e tomou proporções globais. 0 grau de poluição aumentou consideravelmente com o avanço da industrialização e urbanização. Isso não apenas porque a indústria era a principal responsável pelo lançamento de poluentes, mas também porque este momento histórico foi responsável por um grande êxodo rural que povoou desordenadamente as cidades. O capitalismo consolidado e as grandes aglomerações humanas por si só fomentaram graves problemas ambientais como o acúmulo de lixos, enorme volume de esgotos, contaminação de rios e açudes, poluição sonora e da atmosfera.

A perspectiva ética sobre o comércio foi durante todo o início da Idade Moderna quase que totalmente negativa. 0 mundo dos negócios se baseava na tradicional contabilidade do "custo-benefício": agilidade da produção, ampliação das vendas e, consequente, aumento dos lucros. 0 desenvolvimento industrial deveria alcançar valores cada vez maiores para que o consumo se ampliasse e os grandes empresários aumentassem seu capital. Capital este que seria mais uma vez aplicado da indústria, como um ciclo vicioso. Idéias de responsabilidade social da empresa para com o ser humano e com o meio ambiente estavam fora do plano de ação empresarial, pois não se enquadravam no projeto de maximização do lucro.

No século XX, entre as de 60 e 70, uma tendência social tomou parte da Europa e dos Estados Unidos da América. Diversos estudos a respeito da necessidade de responsabilizar a empresa pelas suas ações sociais e ambientais se tornaram evidentes. Tratava-se de reconhecer a empresa, juntamente com o Governo, como instituições ligadas diretamente aos problemas da população. Diversos setores sociais intervieram com críticas relacionadas ao comprometimento unicamente econômico das empresas. Reivindicações passaram a exigir mudanças efetivas na tradicional atuação corporativa empresarial. 


\section{0 desenvolvimento sustentável por meio da Biossegurança e as responsabilidades sociais da empresa}

No Brasil as idéias começaram a ser discutidas com movimentos ativistas. Muitos estudiosos passam a criticar o objetivo único das empresas da época: obtenção de lucro. Alguns ainda mantiveram teses afirmativas sobre ser a atividade produtiva a única responsabilidade social da empresa. Para eles, ao produzir um relógio, por exemplo, a empresa se envolvia na tecnologia e no seu aprimoramento e isso já traria benefícios para a sociedade. Entretanto, com a força do movimento, diversas leis foram criadas visando garantir o respeito das empresas em relação aos seres humanos e ao meio ambiente.

A primeira manifestação positivada de responsabilidade social no Brasil se deu com a criação da Asso ciação dos Dirigentes Cristãos de Empresas (ADCE) e a publicação da "Carta de Princípios do Dirigente Cristão de Empresas", em 1965, como afirma Pessoa (2008). No seu texto introdutório, a Associação enumerava as responsabilidades sociais que, como cristãos, os dirigentes empresariais tinham perante a sociedade. Seus ideais se baseavam na luta por uma ordem social mais justa, uma economia a serviço do homem e um desenvolvimento harmônico embasado na democracia, nos valores da pessoa humana e orientado pelo bem-comum. 0 texto hoje é considerado como um principiante código de ética empresarial.

A difusão dessas idéias, no entanto, tomou impulso a partir da segunda metade dos anos 70 , quando mereceram destaque como ponto central do $2^{\circ}$ Encontro Nacional de Dirigentes de Empresas. Um dos princípios da ADCE Brasil baseava-se na aceitação por seus membros de que as empresas além de produzir bens e serviços, devem possuir função social que se realiza em nome dos trabalhadores e do bemestar da comunidade em geral. (PESSOA, 2008).

Com a pressão social e a mudança paulatina nas ações empresariais, a legislação brasileira acompanhou a tendência, criando leis referentes à responsabilidade da empresa perante 0 trabalhador e o meio ambiente. A Lei № 4.266/63 instituiu o direito ao salário família a todo trabalhador empregado por uma empresa vinculada à Previdência Social, respectivamente ao número de filhos menores de 14 anos do mesmo. A Lei № 5.085/66, reconheceu aos trabalhadores avulsos, inclusive aos estivadores, conferentes e consertadores de carga e descarga, vigias portuários, arrumadores e ensacadores de café e de cacau, o direito a férias anuais remuneradas. As férias, pagas pelos empregadores, seriam

Revista de Direito Público, LondRIna, V. 6, N. 3, P. 120-138, OUT/DEZ. 2011. 
intermediadas pelos sindicatos, que se encarregariam de preencher as condições legais e regulamentares.

Com relação à segurança no trabalho a Lei № 6.514/77 alterou o capítulo $\mathrm{V}$ do Titulo II da Consolidação das Leis do Trabalho, relativo à segurança e medicina do trabalho. Dentre outras providências, a lei em questão instituiu no Art. 166 que é obrigação da empresa fornecer aos seus empregados gratuitamente equipamentos de proteção individual e no art. 168 que fica obrigado ao empregador oferecer o exame médico ao empregado antes da contratação.

0 meio ambiente também foi alvo das leis da década de 60 e 70. A Lei das Florestas № 4.771/65 determinou a proteção de florestas nativas e definiu como áreas de preservação permanente toda a faixa de 30 a 500 metros às margens dos rios, lagos e reservatórios. Além disso, os topos de morros e encostas ficaram protegidos contra qualquer tipo de instalação empresarial. A Lei da Fauna Silvestre № 5.197/67, com o mesmo intuito de proteção ambiental, criminalizou a exportação de peles e couros de anfíbios e répteis em bruto.

Apesar de algumas ideias em contrário, como do economista Milton Friedman, ganhador do prêmio Nobel de economia, que defende que as empresas têm o dever de atender apenas aos seus acionistas e proprietários e que quando se propõem a ir além dos lucros passam a criar políticas de responsabilidade social sem terem sido eleitos por ninguém (TEIXEIRA; TEIXEIRA; FONSECA, 2006, p. 1), a posição socioeconômica mundial acabou realmente mudando. Estudiosos passam a afirmar que as empresas influenciavam significativamente no consumo das pessoas e que estas são responsáveis pelo surgimento e manutenção daquela. Dessa forma a pessoa humana passou a ter valor perante a empresa e essa foi legalmente obrigada a respeitá-la.

Após o período ativista, ocorrido da década de 60 no Brasil, as empresas passam a responder não apenas pelas suas obrigações sociais (responsabilidades econômico-legais fundamentais), mas também pelas suas responsabilidades sociais. Esta obrigação da empresa agrega um imperativo ético às atividades que contribuem para o crescimento e melhoria social. Não se trata mais de estar apenas nos moldes empresariais legais mas também de realizar eticamente ações de alcance social. 


\section{0 desenvolvimento sustentável por meio da Biossegurança e as responsabilidades sociais da \\ empresa}

A responsabilidade social dita as regras que combinam os objetivos econômicofinanceiros com a cidadania, a preservação ambiental e a ética dos negócios, pois 0 fato de se auferir lucros à custa da saúde física e mental dos empregados, da destruição do meio ambiente e do desprezo por uma parcela considerável da sociedade, pode acabar gerando prejuízos a longo prazo. Assim, difunde-se de forma gradativa nos vários setores sociais o compromisso das empresas públicas e privadas - enquanto agentes sociais do processo de desenvolvimento - com a comunidade civil. (TEIXEIRA; TEIXEIRA; FONSECA, 2006, p. 2).

$\mathrm{Na}$ perspectiva contemporânea de responsabilidade social, a empresa esta posicionada em um engajamento social de grande importância para a efetividade dos propósitos humanos. Responsabilidade social das empresas não se liga hoje apenas à filantropia, como definido antigamente, mas principalmente às necessidades mercadológicas vigentes e a duração da própria empresa no tempo. Advém, assim, de uma obrigação que vai além das que lhe são estabelecidas pela lei e pela economia.

Segundo Pessoa (2008) o empresário contemporâneo sabe que uma das formas de permanecer no mercado competitivo é assumir compromisso com o ambiente no qual está inserido e com a satisfação das partes envolvidas. A responsabilidade social da empresa vai além da obrigatoriedade legal e do marketing social, trata-se, dessa forma, de uma gestão estratégica. A empresa assume um compromisso permanente de adotar um comportamento ético para com a sociedade e contribuiu para um desenvolvimento global da sociedade e sua própria efetividade.

\section{Biossegurança e desenvolvimento sustentável: responsabilidades sociais da empresa}

A empresa, instituição incumbida de responsabilidades sociais, deve possuir compromisso ético com seus concorrentes, funcionários e com o meio ambiente onde de insere. De forma mais particular tem-se que a empresa é responsável pela proteção do trabalhador e do meio ambiente. Nesse sentido pode-se dizer que uma instituição empresária tem compromisso ético com a biossegurança, sendo esta, segundo Teixeira e Valle (2002) um conjunto de ações voltadas para a prevenção e proteção do trabalhador, 
que atuam com o propósito de garantir à minimização dos riscos inerentes a atividade de trabalho, a proteção à saúde do homem, dos animais e do meio ambiente.

Este compromisso de tutela da vida, em seu sentido mais amplo, pode ocorrer a partir de uma iniciativa voluntariosa da empresa ou por intervenção normativa do Estado. Evidentemente que a primeira opção seria o ideal porque demonstra uma cultura empresarial de respeito ao meio interferido pela atividade desenvolvida na empresa. No entanto, estas iniciativas nem sempre se confirmam. Resta ao Estado intervir com finalidade de prevenção e precaução.

Estes caminhos conduzem ao desenvolvimento sustentável uma vez que concretizam valores sociais, que se opõem ao individualismo e a tradicional racionalidade econômica do lucro sem considerar os custos necessários da biossegurança.

\section{Conceito de biossegurança}

Em 1941 dois pesquisadores publicaram uma pesquisa que relacionava casos de infecções bacterianas a trabalhos em laboratórios. 0 estudo em questão confirmou que 74 pessoas adquiriram Brucelose devido ao contato com a bactéria referente à doença no ambiente de trabalho. Diversos estudos comprovaram que o contato estava ligado à falta de cuidados ou uma técnica falha dos materiais infecciosos.

Este estudo se aprofundou com Sulkin e Pike. Em 1949 tais pesquisadores publicaram uma série de pesquisas relacionadas a contaminações bacterianas e virais nas quais a maioria dos casos estava ligada a contaminação laboratorial. Começou-se então a pensar na necessidade de exigir das empresas medidas voltadas para a minimização dos riscos para o homem e o meio ambiente. Nesse sentido o Instituto de Saúde dos Estados Unidos publicou em 1976 normas de segurança laboratorial para projetos ligados ao governo. Surgiu assim as primeiras linhas de pesquisa relacionadas à biossegurança.

$\mathrm{Na}$ década de 90 a biossegurança foi direcionada para a tecnologia do DNA recombinante. Surgiram então preocupações ligadas a organismos geneticamente modificados, como os alimentos transgênicos. Como em geral a maioria os países já se utilizava dessa técnica para aumento da produção, surgiu a necessidade de se criar medidas 


\section{0 desenvolvimento sustentável por meio da Biossegurança e as responsabilidades sociais da empresa}

de avaliação dos riscos que eles poderiam causar à saúde humana e ao meio ambiente (BRASIL. Ministério da Saúde, 2004, p.2.)

A partir da década de 90 a palavra biossegurança ganhou espaço nas salas de aulas e nas empresas. Passou-se a discutir suas duas vertentes: a biossegurança como reguladora dos procedimentos de segurança em ambientes biotecnológicos tais como laboratórios e também no sentido da prevenção de riscos gerados por agentes químicos e físicos como indústrias, hospitais e universidades. Atualmente o termo também é utilizado para tratar de questões sobre a saúde do trabalhador, prevenção de acidentes, proteção ao meio ambiente e em todos os casos que envolvem a moderna tecnologia e a vida.

Para o melhor estudo do termo faz-se necessário analisar que a palavra biossegurança é a união de duas outras: "bio" que refere-se a "vida" e "segurança" que, segundo o dicionário Michaelis, significa "estado do que se acha seguro; garantia; proteção". Partindo do significado denotativo das palavras que compõe a palavra estudada tem-se que biossegurança é, essencialmente, proteção da vida.

Sobre esse conceito M ario Hiroyuki Hirata e Mancini Filho (2002, p. 2) diz que:

Adotar-se-á o termo biossegurança como a ciência voltada para o controle e a minimização de riscos advindos da prática de diferentes tecnologias, seja em laboratório seja no meio ambiente. 0 fundamento básico da biossegurança é assegurar 0 avanço dos processos tecnológicos e proteger a saúde humana, animal e o meio ambiente.

Rosário Dominguez Crespo Hirata (apud HIRATA; M ANCINI FILHO, 2002) afirma que é possível diminuir o desenvolvimento de doenças profissionais por exposição a diversos agentes presentes no ambiente de laboratório com a prática de seguras atividades laboratoriais e de medidas que visem preservar a saúde e o meio ambiente. A Comissão de Biossegurança da Fundação Oswaldo Cruz define o conceito de biossegurança de forma abrangente:

[...] considerando-a como um conjunto de ações voltadas para a prevenção, minimização ou eliminação de riscos inerentes às atividades de pesquisa, produção, ensino, desenvolvimento tecnológico e prestação de serviço, as quais possam comprometer a saúde do homem, dos animais, das plantas, do ambiente ou a qualidade dos trabalhos desenvolvidos. (COMISSÃO DE BIOSSEGURANÇA DA FUNDAÇÃO OSWALDO CRUZ, 2003 apud SHM IDLIN, 2005, p. 2)

Revista de Direito Púbuco, Londrina, V. 6, N. 3, P. 120-138, OUT/DEZ. 2011. 
Dentre as doutrinas e legislações abordadas, percebe-se que amplo é o conceito de biossegurança. No estudo em questão vale, porém, ressaltar que será utilizado o conceito mais genérico da palavra. Cabe aqui então o conceito denotativo de que biossegurança é proteção da vida e também aquele abordado por Pedro Teixeira e Silvio Valle (2002) em que biossegurança é um conjunto de ações voltadas para a prevenção e proteção do trabalhador, que atuam com o propósito de garantir à minimização dos riscos inerentes a atividade de trabalho, a proteção à saúde do homem, dos animais e do meio ambiente. 0 conceito será então estudado como eixo para se tratar de segurança humana e desenvolvimento sustentável.

0 reconhecimento da biossegurança no Brasil se deu com o ingresso no programa de treinamento da Organização Mundial da Saúde, o qual visa expandir o conceito na América Latina. Em 1995, com a Lei № 8.974/95 o país formatou legalmente a ideia de biossegurança:

Art. $1^{0}$ - Esta Lei estabelece normas de segurança e mecanismos de fiscalização no uso das técnicas de engenharia genética na construção, cultivo, manipulação, transporte, comercialização, consumo, liberação e descarte de organismo geneticamente modificado (OGM), visando a proteger a vida e a saúde do homem, dos animais e das plantas, bem como o meio ambiente.

A lei restringiu as atividades que envolviam Organismos Geneticamente Modificados apenas aos órgãos Públicos ou Privados responsáveis pelos preceitos da lei em questão e pelas possíveis consequências de atividades dessa natureza. Entre seus aspectos mais relevantes, ela definiu conceitos operacionais ligados à ciência e utilizados pelo Direito. Além disso, positivou a responsabilidade de empresas que provocassem danos ao meio ambiente ou a terceiros e exigiu que toda entidade que utilizasse técnicas e métodos de engenharia genética deveria criar uma Comissão Interna de Biossegurança (CIBio). Por outro lado, indicou um técnico principal responsável por cada projeto específico.

Em 2005, entretanto, a Lei $\mathrm{N}^{-}-11.105 / 2005$ revogou a Lei $\mathrm{N}^{0}-8.974 / 95$ e trouxe novidades ao sistema implantado. Seu Art. 1ํㅗ sofreu algumas alterações. Observe: 


\section{0 desenvolvimento sustentável por meio da Biossegurança e as responsabilidades sociais da empresa}

Art. $1^{0}$ Esta Lei estabelece normas de segurança e mecanismos de fiscalização sobre a construção, o cultivo, a produção, a manipulação, o transporte, a transferência, a importação, a exportação, o armazenamento, a pesquisa, a comercialização, 0 consumo, a liberação no meio ambiente e 0 descarte de organismos geneticamente modificados - OGM e seus derivados, tendo como diretrizes o estímulo ao avanço científico na área de biossegurança e biotecnologia, a proteção à vida e à saúde humana, animal e vegetal, e a observância do princípio da precaução para a proteção do meio ambiente.

A nova lei trouxe, logo no primeiro artigo, referência marcante à proteção ao homem e ao ambiental. Foram estabelecidas normas de segurança e medidas de fiscalização sobre ações que contribuem para a liberação e descarte no meio ambiente de organismos geneticamente modificados e seus derivados. Essas normas tinham como eixo assegurar ampla proteção à vida em geral e à saúde humana, estabelecendo as punições pelo descumprimento dos deveres de prevenção que variam desde a advertência, multa, embargos de atividade até proibição de contratar com a administração pública. Neste sentido o Art. 21 dispõe:

Art. 21. Considera-se infração administrativa toda ação ou omissão que viole as normas previstas nesta Lei e demais disposições legais pertinentes.

Parágrafo único. As infrações administrativas serão punidas na forma estabelecida no regulamento desta Lei, independentemente das medidas cautelares de apreensão de produtos, suspensão de venda de produto e embargos de atividades, com as seguintes sanções [...]:

0 destaque da lei de 2005 se dá em todo 0 âmbito da fiscalização de atividades empresariais de alto risco, o que garante segurança ao trabalhador, à sociedade em geral e ao meio ambiente. Além disso, criou um sistema de informações que proporcionou maior publicidade aos procedimentos.

A efetividade deste sistema jurídico depende, portanto, da implementação de todos os seus mecanismo de prevenção e precaução. 0 Brasil, apesar de ter uma legislação relativamente nova sobre biossegurança, possui um grande arsenal de leis ambientais e trabalhistas que podem e devem se atrelar a essa idéia. Esta constatação possibilita a convivência entre os interesses econômicos que investem em novas tecnologias e os cuidados com a complexidade ambiental e a vida humana com menores riscos e mais qualidade.

Revista de Direito Púbuco, Londrina, V. 6, N. 3, P. 120-138, OUT/DEZ. 2011. 
Conceito de desenvolvimento sustentável

A questão ambiental ligada a qualquer tipo de planos de desenvolvimento surgiu na década de 60 com diversos estudos e pesquisas relacionados à situação ambiental precária em que já se encontrava o planeta. Depois de anos de atividade maquino faturada, iniciadas com a Revolução Industrial, em que esgotos foram despejados sem qualquer controle em rios e fortes poluentes foram emitidos pelas chaminés das grandes fábricas, o homem se deu conta do caos ambiental para onde tendia a terra. Segundo Fábio Taioli e Umberto Cordani, (2009) na época, diversos países manifestaram ser inatingível o desenvolvimento sem prejuízo ao meio ambiente. Eles acreditavam que a poluição e a deterioração de florestas eram uma infeliz conseqüência do desenvolvimento econômico.

Foi durante a Primeira Conferência da ONU sobre o Meio Ambiente e Desenvolvimento, em Estolcomo, Suécia, 1972, que a idéia de proteção ambiental surgiu. A preocupação internacional para com esse assunto se intensificou com a publicação, no mesmo ano, de "Estudos do Crescimento", pesquisa orientada por Dennis Meadows afirmando que se os níveis de atividade industrial e de poluição permanecessem os mesmos, a terra seria estável apenas por mais 100 anos. Com o avanço da consciência global da necessidade do controle da atividade industrial, o canadense Maurice Strong lançou o conceito de eco-desenvolvimento, cujos princípios foram criados por Ignacy Sachs, como afirma Tais Martins $(2003, \mathrm{p} 1)$ :

Os caminhos do desenvolvimento seriam seis: satisfação das necessidades básicas; solidariedade com as gerações futuras; participação da população envolvida; preservação dos recursos naturais e do meio ambiente; elaboração de um sistema social que garanta emprego, segurança social e respeito a outras culturas; programas de educação.

A partir desses debates abriu-se espaço para o conceito de desenvolvimento sustentável que preconiza, segundo Fábio Taioli e Umberto Cordani (2009, p. 523), "um sistema de desenvolvimento sócio-econômico com justiça social e em harmonia com os

Revista de Direito Púbuco, Londrina, V. 6, N. 3, P. 120-138, OUT/DEZ. 2011. 


\section{0 desenvolvimento sustentável por meio da Biossegurança e as responsabilidades sociais da empresa}

sistemas de suporte da vida na Terra." Em seu sentido mais amplo trata-se de uma estratégia que visa promover o equilíbrio entre a humanidade e a natureza, uma visão ética do desenvolvimento subordinado a uma finalidade social.

Atualmente a concepção de desenvolvimento sustentável parece transparente: trata-se da necessidade de se produzir hoje sem comprometer as civilizações futuras. 0 mito de que os recursos naturais são infinitos já foi quebrado e isso possibilita enxergar com clareza a necessidade de preservá-los. Os rios e açudes, quando se tornam locais de despejo de esgotos, ficam inviáveis à utilização humana. Os altos níveis de poluentes emitidos pelas indústrias, como os óxidos de enxofre e monóxido de carbono, são responsáveis por doenças respiratórias e cardiovasculares. Apesar da conscientização global, ainda são irrisórias as ações empresariais de proteção ao meio ambiente.

\section{Biossegurança e a ordem jurídica constitucional}

O desenvolvimento sustentável e a proteção ao indivíduo, como desdobramentos da biossegurança, integram a responsabilidade social da empresa. Isso porque, positivados na Constituição Federal e em diversas leis infraconstitucionais, eles se tornaram não apenas obrigações, mas a solução de diversos problemas empresariais.

Atualmente, um dos grandes desafios das empresas é a questão não somente de compor o domínio econômico, mas, a sua permanência, ou seja, sua longevidade. Antigamente quanto mais lucro gerasse uma empresa, mais interessante ela seria para o acionista. Hoje, permanece a idéia de lucro, mas é interesse do acionista e do Estado que a empresa permaneça no mercado. Para tanto, é preciso encontrar o caminho para a longevidade e, um deles, certamente, é estabelecer um laço de confiança com 0 consumidor. Hoje, ações embasadas no desenvolvimento sustentável são essenciais para a "boa-imagem" da empresa. 0 vínculo referido nasce a partir do momento em que a empresa se porte conforme as normas jurídicas, pois elas representam parâmetros ético-jurídicos mínimos indispensáveis para uma boa convivência com a sociedade.

A Constituição Federal de 1988 trouxe normas-princípios relativas à orientação das empresas no seu planejamento estratégico. 0 artigo 170, por exemplo, preconiza que a ordem econômica deve ser regida pela valorização do trabalho humano, dignidade da 
pessoa, justiça social, utilização da propriedade conforme critérios jurídicos de função social, preservação o meio ambiente e respeito ao consumidor.

Estas normas constitucionais devem orientar toda a ação tanto do Estado quanto das empresas uma vez que compõem o modelo econômico nacional:

0 modelo econômico registrado em nível constitucional a partir de 1988 reúne valores, normas de valores expressivos e limites objetivos, [...]. Os valores e normas constitucionais estão à espera do processo de positivação, para alcançar o patamar das relações humanas, e serem realizadas. (BASSOL, 2007, p. 243).

Neste sentido, ainda no texto constitucional, a intervenção normativa ou de positivação segue nos termos do artigo 225 da Carta Magna Brasileira compondo a ordem jurídica supra referida. 0 texto constitucional comprova a preocupação do constitucionalista ao estabelecer competências aos governos para a defesa da vida tanto humana quanto animal e vegetal, todas dependentes do meio ambiente. Nesse sentido amplo é que deve ser contextualizada a biossegurança:

Art. 225. Todos têm direito ao meio ambiente ecologicamente equilibrado, bem de uso comum do povo e essencial à sadia qualidade de vida, impondo-se ao Poder Público e à coletividade o dever de defendê-lo e preservá-lo para as presentes e futuras gerações.

0 artigo em questão evidencia que cabe a todo ser humano - tratado como Poder Público e coletividade - defender e preservar o meio ambiente para que as gerações futuras possam usufruir dela. Nesta "coletividade" está inserida a empresa. Esta pode ser considerada como conjunto de indivíduos que se movem para a realização de uma atividade voltada para a produção de bens e/ou serviços, é também responsável pela manutenção e proteção do meio ambiente. Essa idéia se relaciona, principalmente, com o fato de a empresa usufruir e manter relação direta com o meio em que está inserida. Não se trata simplesmente de seguir axiomas mundialmente estabelecidos por ambientalistas, contudo de eticamente se responsabilizar pelo que utiliza.

0 direito a integridade do meio ambiente - típico direito de terceira geração constitui prerrogativa jurídica de titularidade coletiva, refletindo, dentro do processo de afirmação dos direitos humanos, a expressão significativa de um

Revista de Direito Púbuico, LondRINA, V. 6, N. 3, P. 120-138, OUT/DEZ. 2011. 


\section{0 desenvolvimento sustentável por meio da Biossegurança e as responsabilidades sociais da empresa}

poder atribuído, não ao indivíduo identificado em sua singularidade, mas, num sentido verdadeiramente mais abrangente, a própria coletividade social. (MS 22.164, Rel. Min. Celso de Mello, DJ 17/11/95). - Constituição Federal Comentada pelo STF).

Sob mesmo âmbito, e por meio de mais um exemplo, pode-se afirmar a tendência de uma atuação compulsória entre os interesses empresarial com a esfera pública, com a lei 12.305/10 criada para disciplinar a questão dos resíduos sólidos. O seu texto expõe parâmetros para uma Política Nacional de Resíduos Sólidos. Com a nova legislação, Estados e Municípios são obrigados a elaborar planos para seus resíduos sólidos juntamente com empresas locais. 0 incentivo à reciclagem e ao reaproveitamento, por toda atividade empresarial, é uma das vertentes da lei, que reiterou a necessidade das empresas estarem focadas em sua responsabilidade para com o meio ambiente.

Com certeza, a preocupação com as soluções sócio-ambientais não estão mais relacionadas ao "romantismo preservacionista" e sim, às medidas de sustentabilidade do próprio negócio, gerenciando a conformidade legal ambiental sob a ótica econômica, evitando dissabores empresariais, com grandes prejuízos em função de imagem institucional, multas, ressarcimento, recuperação de áreas, restrição a contratação por órgãos públicos, financiamentos, dentre outras penalidades. (PEIXOTO, 2010, p. 1)

A lei define conceitos como "área contaminada", "coleta seletiva", "reciclagem" e mesmo "resíduos sólidos" para esclarecer, evitar possíveis confusões e exigir que contratos e acordos entre empresas sejam revistos. 0 artigo $3^{\circ}, \mathrm{XVII}$, define, por exemplo, que a responsabilidade compartilhada pelo ciclo de vida dos produtos é conjunto de atribuições individualizadas e encadeadas dos fabricantes, importadores, distribuidores e comerciantes, dos consumidores e dos titulares dos serviços públicos de limpeza urbana e de manejo dos resíduos sólidos. Tudo isso para minimizar o volume de resíduos sólidos e rejeitos gerados, bem como para reduzir os impactos causados à saúde humana e à qualidade ambiental decorrentes do ciclo de vida dos produtos. Dessa forma, a lei institui que a responsabilidade pelos resíduos sólidos gerados pela produção de um objeto comercializado, por exemplo, não pertence apenas ao comerciante. De forma compartilhada, todos que estiverem presentes na cadeia de produção-comercialização do objeto serão individualmente responsabilizados pelos resíduos sólidos gerados.

Revista de Direito Púbuco, Londrina, V. 6, N. 3, P. 120-138, OUT/DEZ. 2011. 
Além das definições, a lei tem como princípios, como estabelecido no artigo $6^{0}$, prevenção e precaução; o poluidor-pagador e o protetor-recebedor; desenvolvimento sustentável; cooperação entre diferentes esferas do poder público, o setor empresarial e demais segmentos da sociedade; respeito às diversidades locais e regionais; o direito da sociedade à informação e ao controle social; dentre outros.

Conforme se pode avaliar o Direito, por meio de seus mecanismos de positivação, deve ser utilizado para promover a interação entre interesses públicos e privados em favor da sustentabilidade o qual promove a segurança humana. A vantagem da intervenção estatal está na força da compulsoriedade intrínseca do mundo do dever ser. No entanto, a efetividade, quanto a rapidez de resultados para a defesa da vida e do meio do qual depende, acima de tudo, está no engajamento de todos (governos, mercado, sociedade civil), motivados por convencimento de que o desenvolvimento sustentável, que inclui 0 aspecto da biossegurança, é o caminho que harmoniza os diversos interesse que envolvem as relações humanas.

\section{Conclusão}

A empresa cidadã é aquela que atua de modo socialmente responsável. Entre os paradigmas, para assim ser qualificada, tem-se aqueles que demarcam o conceito contemporâneo de sustentabilidade, isto é, atuação ética nos âmbitos econômico, ambiental e social.

No aspecto econômico é lícito à empresa auferir lucro. É fundamental que permaneça atuando no mercado e que faça investimentos em novas tecnologias que possam melhorar a condição humana. No entanto, o limite do lucro e dos investimentos está na responsabilidade pela qualidade e segurança do seu produto, em respeito ao consumidor .

No aspecto ambiental a empresa deve em sua atuação respeitar, no mínimo, as leis que têm por finalidade prevenir e proibir ações ou omissões que coloquem em riso este complexo sistema e do qual depende a vida humana. Toda inovação tem riscos e que podem atingir de modo irreparável o meio. Assim, para agir com segurança a empresa deve ter cuidados em todo o processo produtivo, ou seja, desde o tratamento dos seus resíduos sólidos, da matéria-prima, das embalagens, do transporte, até chegar ao consumo final.

Revista de Direito Púbuco, Londrina, V. 6, N. 3, P. 120-138, OUT/DEZ. 2011. 


\section{0 desenvolvimento sustentável por meio da Biossegurança e as responsabilidades sociais da empresa}

No aspecto social a empresa deve valorizar o trabalho humano. Assim estará agindo se respeitar a legislação que tutela esta relação jurídica. Tais normas representam muitas lutas e conquistas dos trabalhadores, confirmadas por relatos históricos. 0 resultado econômico das empresas depende da qualidade de vida dos seus trabalhadores.

Assim, considerando o disposto da legislação brasileira, Lei ํo 11.105/2005, pode-se afirmar que está em consonância com o conceito de sustentabilidade. Ela estabelece em seu Art. $1^{\text {OO}}$ as diretrizes para sua interpretação e aplicação, ou seja, é dever das empresas e de todos que lidam com o desenvolvimento cinetífico-econômico respeitar as normas de segurança, submetendo-se aos mecanismos de fiscalização sobre a construção, o cultivo, a produção, a manipulação, o transporte, a transferência, a importação, a exportação, 0 armazenamento, a pesquisa, a comercialização, o consumo, a liberação no meio ambiente e o descarte de organismos geneticamente modificados - OGM e seus derivados. A finalidade é permitir a atuação com segurança por meio da proteção à vida, à saúde humana, animal e vegetal, e a observância do princípio da precaução para a proteção do ambiente.

A interação entre a intervenção estatal e a atuação das empresas é fundamental para o desenvolvimento sustentável. Os avanços tecnológicos com segurança dependem desta atuação em parceria. Cada empresa deve cobrar ações deste comprometimento dos demais agentes econômicos, tais como seus fornecedores. Desta forma, constrói-se uma cadeia, cujo resultado será a real possibilidade de oportunidades de acessos às tecnologias e a preservação de qualidade da vida.

\section{Referência}

ASHLEY, Patrícia Almeida. Ética e responsabilidade social dos negócios. 2: ed. São Paulo: Saraiva, 2005.

BASSOL, Kempfer Marlene. Dever de intervenção do estado na ordem econômica por meio da função normativa. In: FERREIRA, Jussara Suzi Assis Borges Nasser; RIBEIRO, Maria de Fátima (Org.). Direito Empresarial Contemporâneo. M arília: UNIM AR, 2007. Cap. 8.

BRASIL. M inistério da Saúde. Biossegurança: em laboratórios biomédicos e microbiologia. Brasília, 2004.

Revista de Direito Público, LondRINA, V. 6, N. 3, P. 120-138, OUT/DEZ. 2011. 
GARSCHAGEN, Donaldson M agalhães. Da Revolução Industrial Inglesa ao Imperialismo. Rio de Janeiro: Forense Universitária, 1998.

HIRATA, Mario Hiroyuki; M ANCINI FILHO, Jorge. Manual de Biossegurança. Barueri: Manole, 2002.

MARTINS, Taís. O conceito de desenvolvimento sustentável e seu contexto histórico. Revista Jus Navigandi: 2003.

MICHAELIS, dicionário de português on-line. Disponível em: ‘ttp://michaelis.uol.com.br>. Acesso em: 10 mar. 2011.

PEIXOTO, Cássio dos Santos. Política Nacional de Resíduos Sólidos (PNRS) e adequação das Empresas. 2010. Disponível em: «ttp://noticias.ambientebrasil.com.br/artigos/2010>. Acesso em: 21 mar. 2011.

PESSOA, Gerisval Alves. Responsabilidade Social das Empresas. Revista on-line Artigonal, 2008. Disponível em: \ttp://www.artigonal.com>. Acesso em: 1 mar. 2011.

RODRIGUEZ, Martuis V. Ética e responsabilidade Social nas Empresas. Rio de Janeiro: Elseiver, 2005.

SCHM IDLIM, K. C. S. Biossegurança na Estética: equipamentos de proteção individual - EPIs. Revista Personalité, São Paulo, ano 8, n. 44, p. 80-101, dez. 2005.

TAIOLI, Fabio; CORDANI, Umberto. A terra, a humanidade e o desenvolvimento sustentável. In: . Decifrando a Terra. Rio de Janeiro: Nacional, 2009. Cap. 28.

TEIXEIRA, Ivandi Silva; TEIXEIRA, Regina Cleide Figueiredo da Silva; FONSECA, Elma Andréa Figueiredo. Comprometimento social das empresas uma questão de ética empresarial. In: SIM POSIO DE ENGENHARIA DE PRODUÇÃO- SIM PEP, 8., 2006, Bauru. Anais... Bauru, 2006.

TEIXEIRA, Pedro; VALLE, Silvio. Biossegurança: uma abordagem multidisciplinar. Rio de Janeiro: Ed. Fiocruz, 2002.

Artigo recebido em:

16 ago. 2011

Artigo aprovado em: 03 nov. 2011 